\title{
Akut Böbrek Hasarı: Yeni Terminoloji, Yeni Sınıflandırma ve Yeni Yaklaşımlar
}

\author{
Umut Selda BAYRAKCI
}

SBÜ Ankara Çocuk Sağlığı ve Hastalıkları, Hematoloji Onkoloji Eğitim Araştırma Hastanesi, Çocuk Nefroloji Kliniği, Ankara, Türkiye Yıldııım Beyazıt Üniversitesi, Tıp Fakültesi, Çocuk Nefroloji Bilim Dalı, Ankara, Türkiye

Böbrek perfüzyonunun yetersiz olması, arterial veya venöz oklüzyon, renal hücre hasarı ve idrar akımının tamamen tıkanması sonucu ortay çıkan tabloya "akut böbrek hasarı" adı verilmektedir. Akut böbrek hasarının sıkığı son yıllarda, özellikle hastanede yatan hastalar arasında, belirgin bir artış göstermektedir. Bunun temel nedenleri arasında yeni gelişen tedaviler, organ ve doku transplantasyonunun yaygınlaşması, oldukça kompleks ameliyatların daha sık yapılmaya bașlanması ve daha çok hastanın yoğun bakım desteğine erișerek, yașam beklentisinin uzamıș olması sayılabilir. Yoğun bakım ünitesinde yatan erișkinler arasında akut böbrek hasarı gelișme sıkı̆ı̆ı \%25 olarak bildirilmiștir $(1,2)$. Kardiyak cerrahi sonrası çocuklarda akut böbrek hasarı sıklğı \%30 ile \%65 arasında değişirken, kardiyak problemi olmayan çocuk yoğun bakım hastalarında akut böbrek hasarı sıklı̆ı \%10 ile \%80 arasında değișmektedir (3). Akut böbrek hasarı yoğun bakım hastalarında sık rastlanan bir sorun olmanın yanı sıra mortalite ve morbiditeyi belirleyen en önemli faktörlerden biridir. Mortaliteyi diğer tüm değișkenlerden bağımsız olarak etkilediğini gösteren pek çok çalıșma vardır (1). Geçmiș yıllarda "akut böbrek yetmezliği" olarak tanımlanan bu klinik durum bir süre önce isim değiştirmiş ve "akut böbrek hasarı" olarak literatürdeki yerini almıştır (4). Yapılan geniş kapsamlı çalışmalar ile akut renal hasarın patogenezinin kabaca tanımlanması ve altta rol oynayan histolojik olayların kısmen açıklanması sonucu tanım değişikliğine gidilmiş ve daha çok temel bilimlere gönderme yapan yeni bir isim alarak, popüler kullanıma girmiştir. Bu yeni tanım daha önce sıkıkla kullandığımız ve önemsediğimiz pre-renal böbrek yetmezliğini kapsamayıp daha çok geri-dönüșümsüz böbrek hasarı ile ilgilenmektedir. Bu yeni tanımla birlikte akut böbrek hasarı yeni bir sınıflandırmaya da kavușmuștur: "RIFLE kriterleri". RIFLE kriterleri ilk olarak erişkin hastalar için tanımlanmıştır. Akut böbrek hasarının erken saptanması, prognozunun ve mortalite üzerine olan etkisinin daha objektif bir şekilde ve tüm dünyada kullanılacak, standart verilerle ifade edilmesi amaçlanmıştır. Daha sonra Arıkan et al. (3) bu verileri çocuk hastalara uyarlayarak "pediatrik RIFLE" kriterlerini oluşturmuşlardır. Literatürde akut böbrek hasarı için kullanılan yaklaşık 35 farklı tanımlama mevcuttur. Bu farklı tanımlamalarla yapılan insidans, mortalite ve morbidite çalışmalarının bilime katkı sağlayamayacağı aşikârdır. Bunun üzerine pediatrik RIFLE kriterlerinin geçerliliği yoğun bir şekilde çalışılmış ve çocuk hastalarda akut böbrek hasarının tanımlanması ve sınıflandııımasında kullanılması önerilmiştir.

Dergimizde yayınlanan "Akut Böbrek Hasarı: Sınıflandırıması ve Prognoz" başlıklı makalede de Şen ve Çakar pediatrik RIFLE kriterlerini kullanarak, çocuk hastalarda akut böbrek hasarının etiyolojisini, klinik özelliklerini ve prognoz üzerine etkili olan faktörleri araștırmıșlardır. Bu çalıșmada pediatrik RIFLE sınıflamasının, diyaliz gereksinimini ve hasta mortalitesini önceden tahmin etmede oldukça etkin bir yöntem olduğu sonucuna varımıştır (5). Sağlık Bilimleri Üniversitesi, Ankara Çocuk Sağlığı ve Hastalıkları, Hematoloji-Onkoloji Eğitim Araştırma Hastanesi'nde, akut renal hasar nedeniyle izlenen çocukların verilerinin prospektif olarak değerlendirildiği bu çalısmada; hastaların \%15'inin risk, \%25'inin hasar ve \%60'ının yetmezlik grubunda olduğu gösterilmiştir. Diyaliz intiyacı olan hastaların \%80'inin, kronik böbrek hasarı geliştiren hastaların hepsinin yetmezlik grubunda olması, pediatrik RIFLE kriterlerinin hasta takibinde güvenle kullanılabileceğini göstermektedir. Uygulamada da son derece kolay olan bu değerlendirme sisteminin ülkemizde de yaygınlaşması ve farkındalığın artması için bu konuda eğitici çalışmalara ve yayınlara intiyaç vardır. 


\section{KAYNAKLAR}

1. Bouchard J, Acharya A, Cerda J, Maccariello ER, Madarasu $\mathrm{RC}$, Tolwani AJ, et al. A prospective international multicenter study of $\mathrm{AKI}$ in the intensive care unit. Clin J Am Soc Nephrol 2015;10:1324-31.

2. Vincent JL, Marshall JC, Ñamendys-Silva SA, François B, MartinLoeches I, Lipman J, et al. Assessment of the worldwide burden of critical illness: The Intensive Care Over Nations (ICON) audit. Lancet Respir Med 2014;2:380-6.
3. Akcan-Arıkan A, Zappitelli M, Loftis LL, Washburn KK, Jefferson LS, Goldstein SL. Modified rifle criteria in critically ill children with acute kidney injury. Kidney Int 2007;71:1028-35.

4. Sudhir Shah M, Lieberthal W, Mehta R, Molitoris B, Okusa M, Rabb $\mathrm{H}$ et al. American Society of Nephrology renal research report. J Am Soc of Nephrol 2005;16:1886-903.

5. Şen Savaș Z, Çakar N. Akut böbrek hasarı: Sınıflandırma ve prognoz. Türkiye Çocuk Hast Derg 2018;12:180-85. 